\title{
PERAMALAN PENGGUNAAN BEBAN LISTRIK JANGKA PENDEK GARDU INDUK BAWEN DENGAN DSARIMA
}

\author{
Marita Saptyani $^{1}$, Winita Sulandari ${ }^{2}$, Pangadi $^{2}$ \\ ${ }^{2}$ Staf Pengajar Jurusan FMIPA UNS \\ winita@mipa.uns.ac.id
}

\begin{abstract}
Bawen substation is a part of electrical distribution system. Forecasting load demand is required for power planning. Data used in this research are an hourly load demand of Bawen, Salatiga for 3 months, from February 2, 2013 to April 29, 2013, measured in Megawatt (MW).A half hourly load demand forecasting is needed for real time controlling and short-term maintenance schedulling. Since the data have two seasonal periods, i.e. daily and weekly seasonality with length 48 and 336 respectively, the model of double seasonal ARIMA (DSARIMA) is proposed as the most appropriate model for the case. Initial model is determined by the pattern of the data, based on the autocorrelation function plot. Some experiments was done by choosing several periods data. The most suitable model is chosen based on the outsample mean absolute percentage error (MAPE). The current study shows that the DSARIMA $(0,1,[1,20,47])(0,1,1)^{48}(0,1,0)^{336}$ is the best model to forecast 336 next period.
\end{abstract}

Keywords: DSARIMA, MAPE, Electricity, Bawen

\section{Pendahuluan}

Berdasarkan Undang-Undang nomor 30 tahun 2009 tentang ketenagalistrikan $^{[5]}$, tenaga listrik adalah suatu bentuk energi sekunder yang dibangkitkan, ditransmisikan, dan didistribusikan untuk segala macam keperluan, tetapi tidak meliputi listrik yang dipakai untuk komunikasi, elektronika, atau isyarat. Perseroan Terbatas Perusahaan Listrik Negara (PT. PLN) yaitu badan milik negara yang menyediakan listrik bagi konsumen. Menurut PT. PLN Penyaluran dan Pusat Pengaturan Beban (P3B) ${ }^{[9]}$, menyatakan fungsi utama dari gardu induk (GI) antara lain mengatur aliran daya listrik dari saluran transmisi ke transmisi lainnya yang kemudian didistribusikan ke konsumen.

Meningkatnya kebutuhan dan jumlah konsumen berbanding lurus denganmeningkatnya permintaan beban listrik dari waktu ke waktu. Jika permintaan lebih besar daripada persediaan maupun sebaliknya maka terjadi pemborosan listrik dan kegagalan sistem. Peramalan penggunaan beban listrik jangka pendek diperlukan untuk kontrol maupun bahan pertimbangan dalampenjadwalan pemeliharaan sistem tenaga listrik dalam upaya mengurangi masalah yang timbul akibat tidak seimbangnya permintaan dan persediaan.

Penelitian tentang peramalan penggunaan beban listrik jangka pendek di Mengare Gresik Indonesia untuk skala perjam telah dilakukan Suhartono dan Endharta[10]. Model peramalan yang digunakan dalam penelitian tersebut adalah model DSARIMA dan Elman-recurrent neural network. Peneliti lain, seperti Ismail, et $a l .{ }^{[4]}$ dan Mohamed, et al. ${ }^{[6],[7]}$ menentukan model peramalan beban listrik jangka pendek di Malaysia. Dalam penelitiannya, Ismail et al. ${ }^{[4]}$ membandingkan seasonal autoregressive integrated moving average (SARIMA) dan autoregressive integrated moving average (ARIMA) untuk peramalan dalam skala perjam yang dipengaruhi satu 
pola musiman. Sementara, Mohamed et al. ${ }^{[6],[7]}$, menggunakan DSARIMA untuk membandingkan kinerja $k$-langkah peramalan penggunaan beban listrik skala persetengah jam yang dipengaruhi dua musiman yaitu musiman mingguan dan musiman harian. Pada penelitian berikutnya, Mohamed et al. ${ }^{[8]}$, membandingkan model SARIMA dan DSARIMA untuk peramalan jangka pendek penggunaan beban listrik di Malaysia skala persetengah jam.

Pada penelitian ini DSARIMA diterapkan untuk meramalkan data runtun waktu penggunaan beban listrik jangka pendek GI Bawen dalam skala waktu persetengah jam yang memiliki pola dua musiman. Beberapa percobaan data in sample dilakukan untuk membangun model. Dengan demikian diperoleh beberapa model dugaan untuk selanjutnya dipilih satu model terbaik berdasarkan nilai mean absolute percentage error (MAPE) out sample.

\section{Metode Penelitian}

Pada penelitian ini, data yang digunakan adalah data sekunder penggunaan beban listrik GI Bawen (dalam mega watt) skala persetengah jam. Data diambil dari PT.PLN P3B Jawa-Bali area pelaksana pemeliharaan Salatiga. Data penggunaan beban listrik pada untuk periode 2 Febuari 2013 sampai 29 April 2013 dibagi menjadi data in sample dan out sample. Data in sample digunakan untuk membangun model sedangkan data out sampel, yaitu 336 data data terakhir digunakan untuk validasi model.

Beberapa data in sample dipilih terhitung mundur dari tanggal 22 April 2013 pukul 23.00 WIB. Dalam hal ini ada 34 kelompok data in sample. Kelompok pertama diperoleh dari 500 data terhitung mundur dari 22 April 2013 pukul 23.00, Kelompok ke dua diperoleh dari 600 data terhitung mundur dari 22 April 2013 pukul 23.00, dan seterusnya. Langkah-langkah yang dilakukan dalam penelitian ini adalah (1) identifikasi pola data pada setiap periode pemotongan, (2) identifikasi pembentukan model dari plot fungsi autokorelasi untuk menentukan orde $q$ dan plot fungsi autokorelasi parsial untuk menentukan orde $p$ pada data yang telah stasioner, (3) melakukan estimasi parameter dengan menggunakan metode kuadrat terkecil, (4) melakukan uji diagnosa yaitu ujikerandoman residu dengan Ljung-Box dan uji kenormalan residu dengan Kolmogorov-Smirnov, (5) pemilihan model terbaik menggunakan data out sample, dengan memilih model yang nilai MAPE terkecil, dan (6) melakukan peramalan pada 336 periode ke depan data penggunaan beban listrik dengan model terbaik.

\section{Model DSARIMA}

Model DSARIMA merupakan model ARIMA yang mengandung pola dua musiman. ARIMA yaitu model runtun waktu yang stasioner setelah dilakukan pembedaan orde $d$. Model ARIMA merupakan kombinasi dari model autoregressive $(A R)$ dan moving average $(M A)$. AR menunjukkan adanya keterkaitan antara suatu nilai pada waktu sekarang $\left(Z_{t}\right)$ dengan nilai pada waktu sebelumnya $\left(Z_{t-1}, \ldots, Z_{t-p}\right)$ ditambah dengan residu pada saat $t\left(a_{t}\right)$. Menurut Wei ${ }^{[12]}, A R$ dengan orde $p$ yang dinotasikan dengan $A R(p)$ adalah

$$
\phi_{p}(B) Z_{t}=a_{t}
$$

dengan $a_{t}$ suatu proses white noise, $E\left(a_{t}\right)=0$, dan $\operatorname{var}\left(a_{t}\right)=\sigma^{2}$. Selain itu, $\phi_{p}(B)$ sebagai operator $A R$ orde $p$. $M A$ menunjukkan adanya keterkaitan antara nilai pada waktu sekarang $\left(Z_{t}\right)$ dengan nilai residu pada waktu-waktu $\left(a_{t-1}, \ldots, a_{t-q}\right)$. Menurut $\mathrm{Wei}^{[12]}, M A$ dengan orde $q$ dinotasikan $M A(q)$ adalah 


$$
Z_{t}=\theta_{q}(B) a_{t}
$$

dengan $\theta_{q}(B)$ adalah operator $M A$ orde $q$.Model ARIMA yang mengandung musiman sering disebut SARIMA. Menurut Wei [12], secara matematis model SARIMA adalah

$$
\phi_{p}(B) \Phi_{P}\left(B^{S}\right)(1-B)^{d}\left(1-B^{S}\right)^{D} Z_{t}=\theta_{q}(B) \Theta_{Q}\left(B^{S}\right) a_{t}
$$

dengan $\Phi_{P}\left(B^{S}\right)$ sebagai operator parameter $A R$ musiman orde $P, \Theta_{Q}\left(B^{S}\right)$ sebagai operator parameter $M A$ musiman orde $Q$, dan $\left(1-B^{S}\right)^{D}$ sebagai operator pembeda musiman dengan orde $D$.

Menurut Box ${ }^{[1]}$ model DSARIMA merupakan model SARIMA yang mengalami perkembangan dengan dua musiman berbeda. Mengacu penelitian Mohamed et al. ${ }^{[8]}$, model DSARIMA $(p, d, q)(P, D, Q)^{S 1}(P, D, Q)^{S 2}$ dengan musiman harian dilambangkan $S_{1}$ dan musiman mingguan dilambangkan $S_{2}$, dituliskan

$$
\begin{gathered}
\phi_{p}(B) \Phi_{P 1}\left(B^{S 1}\right) \Pi_{P} 2\left(B^{S 2}\right)(1-B)^{d}\left(1-B^{S 1}\right)^{D 1}\left(1-B^{S 2}\right)^{D 2} Z_{t} \\
=\theta_{q}(B) \Theta_{Q 1}\left(B^{S 1}\right) \Psi_{Q 2}\left(B^{S 2}\right) a_{t}
\end{gathered}
$$

dengan $Z_{t}$ adalah beban listrik ke $t, \Phi_{P 1}\left(B^{S 1}\right)$ sebagai operator parameter $A R$ musiman $S_{1}$ orde $P_{1}, \Pi_{P 2}\left(B^{S 2}\right)$ sebagai operator parameter $A R$ musiman $S_{2}$ orde $P_{2}$, $\Theta_{Q 1}\left(B^{S 1}\right)$ sebagai operator parameter $M A$ musiman $S_{1}$ orde $Q_{1}, \Psi_{Q}\left(B^{S 2}\right)$ sebagai operator $M A$ musiman $S_{2}$ orde $Q_{2},\left(1-B^{S 1}\right)^{D 1}$ sebagai operator pembeda musiman $S_{1}$ dengan orde $D_{1}$, dan $\left(1-B^{S 2}\right)^{D 2}$ sebagai operator pembeda musiman $S_{2}$ dengan orde $D_{2}$.

\section{Pembahasan}

Data penggunaan beban listrik GI Bawen skala persetengah jam dibagi menjadi data in sample dan data out sample. Selanjutnya, identifikasi pola pada data berdasarkan plot runtun waktu.

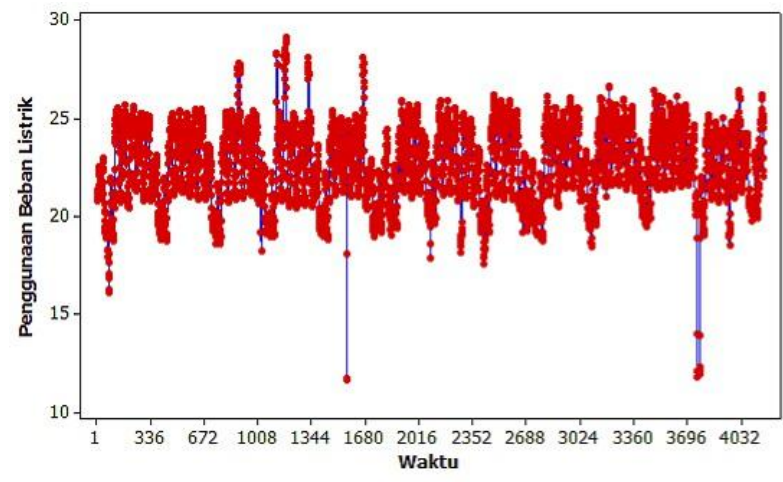

(a)

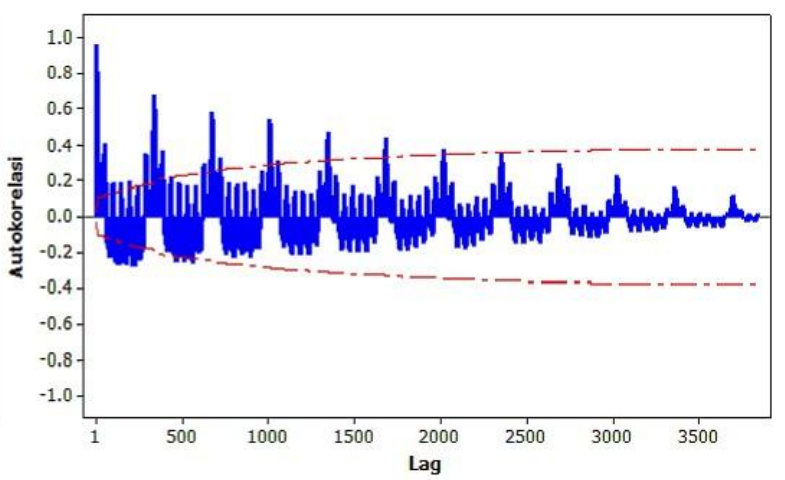

(b)

Gambar 1. (a) Plot Runtun Waktu Beban Listrik GI Bawen dan

(b) Plot Fungsi Autokorelasi Beban Listrik GI Bawen

Gambar 1(a) menunjukkan pola data penggunaan beban listrik memuat kejadian berulang pada periode tertentu karena adanya pengaruh musiman. Selain itu, Gambar 1(b) memperlihatkan ada pengaruh dua musiman yaitu musiman harian periode 48 dan musiman mingguan periode 336 dan tidak stasioner. Menurut Taylor et al. ${ }^{[11]}$ periode musiman harian 48 dan mingguan 336 untuk data beban listrik skala persetengah jam. Hal ini menunjukkan data tidak stasioner dan ada pengaruh dua musiman. Langkah selanjutnya, identifikasi pembentukan model dilakukan dari 34 pembagian data in sample. Proses pembentukan model diawali dengan identifikasi orde model dari data yang stasioner. Data stasioner didefinisikan sebagai data yang nilai rata-ratanya tidak berubah dari waktu ke waktu. Pada setiap kelompok data in sample yaitu 500, 600, 700, 800, 900, 1000, 1100, 1200, 1300, 1400, 1500, 
1600, 1700, 1800, 1900, 2000, 2100, 2200, 2300, 2400, 2500, 2600, 2700, 2800, $2900,3000,3100,3200,3300,3400,3500,3600,3700$, dan 3840 memiliki pola data yang sama.
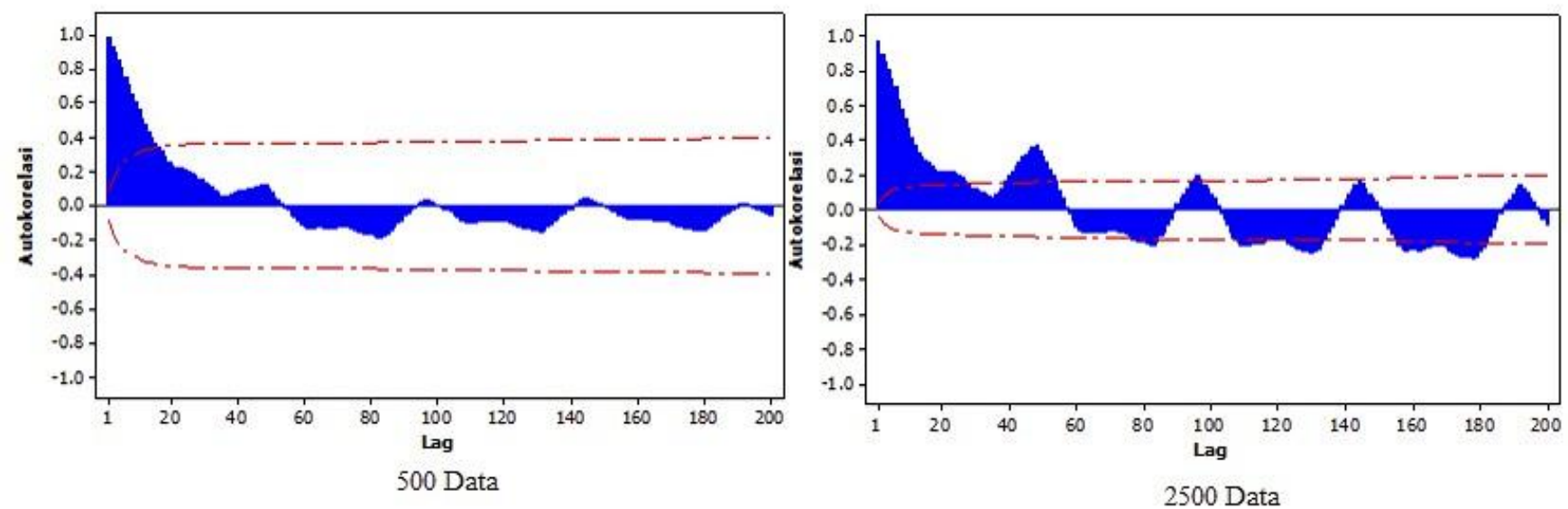

Gambar 2. Plot Fungsi Autokorelasi Data In Sample Beban Listrik GI Bawen

Gambar 2 memperlihatkan sebagian pola data dari 34 bagian pemotongan yaitu 500 dan 2500. Terlihat bahwa data belum stasioner karenalag pertama keluar dari batas signifikansi dan turun perlahan menuju nol. Menurut Hanke dan Dean ${ }^{[3]}$, ciri-ciri pola trendadalah adanya korelasi yang tinggi antar data pada waktu yang berurutan, dan lag pertama keluar dari batas interval kepercayaan kemudian turun perlahan menuju nol. Dengan demikian, Gambar 2 menunjukkan bahwa data penggunaan beban listrik memiliki pengaruh trend. Oleh karena itu perlu pembedaan 1 untuk menghilangkan pengaruh trend.
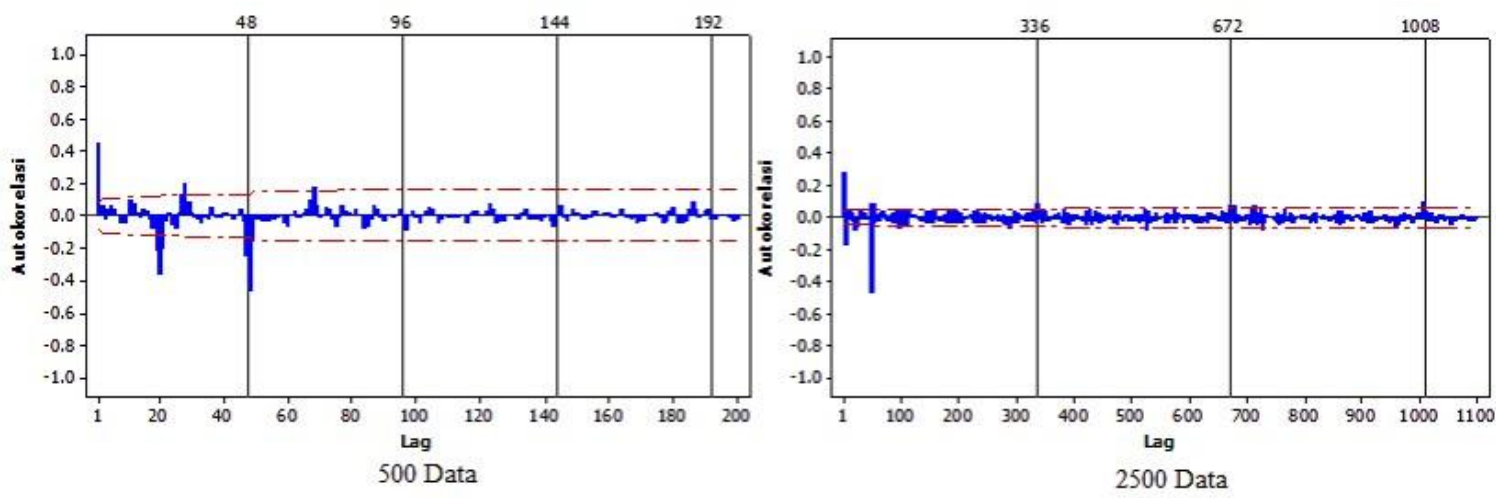

Gambar 3. Plot Fungsi Autokorelasi Data In Sample Beban Listrik GI Bawen Pembedaan 1

Sebagaimana ditulis Hanke dan Dean $^{[3]}$, pola musiman ditunjukkan dengan munculnya perulangankoefisien korelasi yang tinggi pada lag-lag tertentu. Berdasarkan Gambar 3 terlihat ada perulangan pada lag-lag kelipatan 48 yang menunjukkan adanya pola musiman harian. Kemudian, dilakukan pembedaan 48 untuk menghilangkan pengaruh musiman harian. 

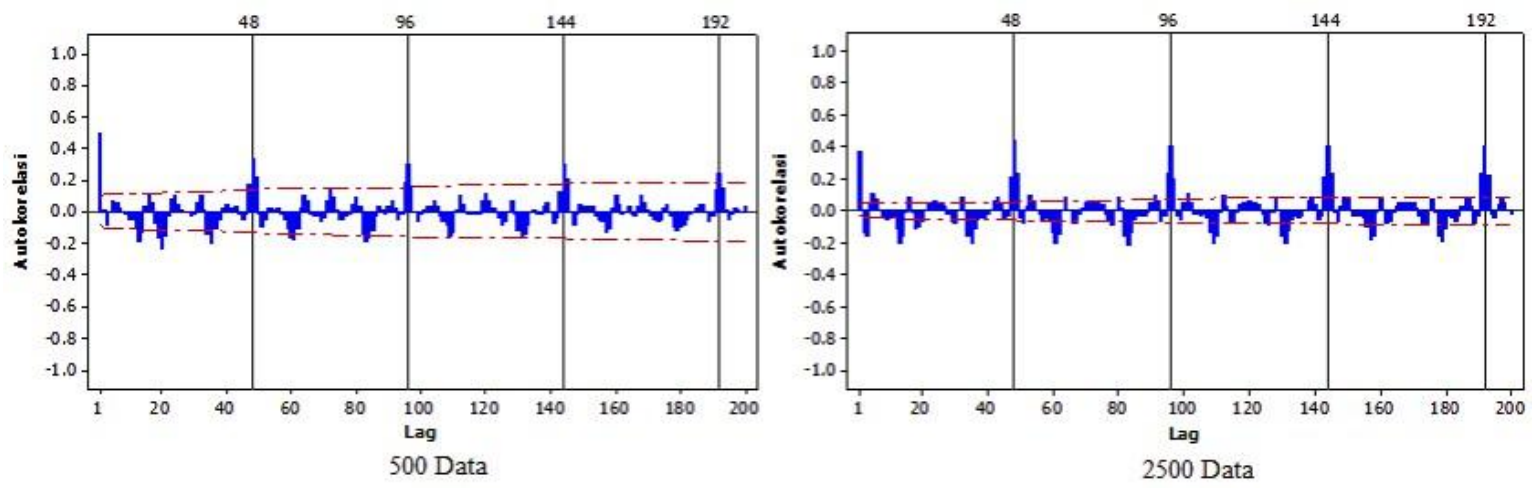

Gambar 4. Plot Fungsi Autokorelasi Data In Sample Beban Listrik GI Bawen Pembedaan 1 dan 48

Gambar 4 memperlihatkan data in sample penggunaan beban listrik GI Bawen belum stasioner. Masih terdapat perulangan lag untuk setiap kelipatan 336, yang merupakan indikasi adanya pola musiman mingguan. Dengan demikian perlu dilakukan pembedaan 336 pada data yang sebelumnya telah melalui proses pembedaan 1 dan 48 .

Hasil pembedaan 1, 48 dan 336 untuk kelompok data in sample 600 ditunjukkan pada Gambar 5. Untuk kelompok data in sample yang lain memiliki plot yang serupa. Fungsi autokorelasi dan autokorelasi parsial pada Gambar 5 dapat digunakan sebagai dasar dalam menentukan orde $p, q, P_{1}, Q_{1}, P_{2}$, dan $Q_{2}$. Berdasarkan pengamatan terhadap lag-lag yang keluar dari batas interval kepercayaan plot autokorelasi dan autokorelasi parsial diperoleh 102 model dugaan. Selanjutnya, parameter model dugaan diestimasi menggunakan metode kuadrat terkecil.

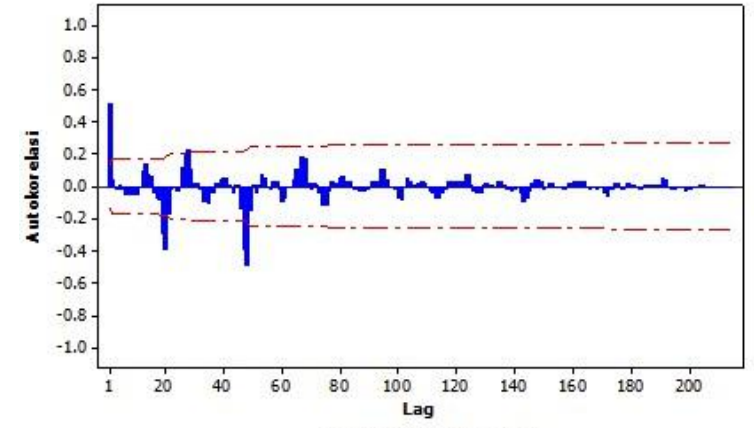

(a) Plot Autokorelasi

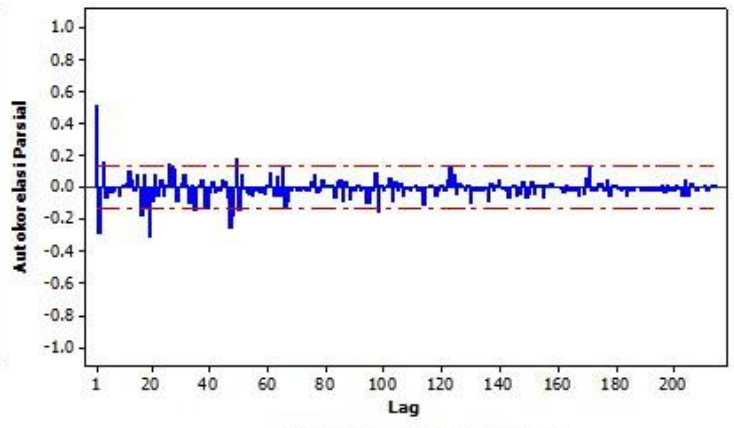

(b) Plot Autokorelasi Parsial

Gambar 5. Plot Data In Sample Beban Listrik GI Bawen Terpotong 600 Pembedaan 1, 48 dan 336

Hasil parameter model selanjutnya diuji dengan menggunakan uji $t$. Berdasarkan uji parameter, diperoleh 15 dari 102 model dugaan memiliki parameter yang signifikan dengan $p$-value lebih kecil dari $\alpha=0,05$. Model-model dengan parameter yang signifikan berikut hasil perhitungan MAPE out sample ditunjukkan pada Tabel 1. 
Tabel 1. Beberapa Model dengan Parameter yang Signifikan

\begin{tabular}{|c|c|c|}
\hline Jumlah & Model & $\begin{array}{c}\text { MAPE Out Sample } \\
(\%)\end{array}$ \\
\hline 500 & $\operatorname{DSARIMA}([1,2,3,19,47], 1,0)(1,1,0)^{48}(0,1,0)^{336}$ & 13,47 \\
\hline 600 & $\operatorname{DSARIMA}(0,1,[1,20,47])(0,1,1)^{48}(0,1,0)^{336}$ & 6,09 \\
\hline 700 & DSARIMA $([1,2,19,20,47], 1,0)(1,1,0)^{48}(0,1,0)^{336}$ & 9,21 \\
\hline 700 & $\operatorname{DSARIMA}(0,1,[1,19,20,21])(0,1,1)^{48}(0,1,0)^{336}$ & 6,94 \\
\hline 800 & DSARIMA $([1,2,19,20,47], 1,0)(1,1,0)^{48}(0,1,0)^{336}$ & 10,39 \\
\hline 800 & $\operatorname{DSARIMA}(0,1,[1,19,20])(0,1,1)^{48}(0,1,1)^{336}$ & 7,14 \\
\hline 800 & $\operatorname{DSARIMA}(19,1,[1,19])(0,1,1)^{48}(0,1,0)^{336}$ & 7,33 \\
\hline 900 & $\operatorname{DSARIMA}([1,2,19,20,27,48], 1,0)(1,1,0)^{48}(0,1,0)^{336}$ & 9,32 \\
\hline 900 & $\operatorname{DSARIMA}(0,1,[1,20,47,48])(0,1,1)^{48}(0,1,0)^{336}$ & 11,76 \\
\hline 1500 & $\operatorname{DSARIMA}([1,2,20], 1,48)(0,1,0)^{48}(0,1,1)^{336}$ & 6,36 \\
\hline 1600 & $\operatorname{DSARIMA}([1,2,19,20,47,48], 1,0)(1,1,0)^{48}(1,1,0)^{336}$ & 8,53 \\
\hline 2400 & $\operatorname{DSARIMA}([1,2,5], 1,[1,2,3,19,20])(0,1,1)^{48}(0,1,1)^{336}$ & 8,79 \\
\hline 3100 & $\operatorname{DSARIMA}(0,1,[1,2,3,19,20])(0,1,1)^{48}(0,1,1)^{336}$ & 50,23 \\
\hline 3200 & $\operatorname{DSARIMA}([2,3,5,20], 1,[1,2,3])(0,1,1)^{48}(0,1,1)^{336}$ & 50,23 \\
\hline 3500 & $\operatorname{DSARIMA}(1,1,[1,2,3])(0,1,1)^{48}(0,1,1)^{336}$ & 47,57 \\
\hline
\end{tabular}

Berdasarkan Tabel 1, model $\operatorname{DSARIMA}(0,1,[1,20,47])(0,1,1)^{48}(0,1,0)^{336}$ memiliki nilai $M A P E$ terkecil. Secara matematis model tersebut dapat ditulis

$$
\begin{aligned}
& Z_{t}(1-B)\left(1-B^{48}\right)\left(1-B^{336}\right) \\
& \quad=\left(1+0.5108 B-0.2533 B^{20}-0.1422 B^{47}\right)\left(1-0.9368 B^{48}\right) a_{t}
\end{aligned}
$$

Namun demikian, model $\operatorname{DSARIMA}(0,1,[1,20,47])(0,1,1)^{48}(0,1,0)^{33}{ }^{6}$ belum dapat dipilih untuk meramalkan penggunaan beban listrik sebelum diketahui bahwa model tersebut layak untuk digunakan. Model dikatakan layak atau sesuai dengan data ketika memenuhi uji diagnostik, yaitu residu bersifat random dan berdistribusi normal. Dari 15 model hanya model $\operatorname{DSARIMA}(0,1,[1,20,47])(0,1,1)^{48}(0,1,0)^{336}$ yang memenuhi uji kerandoman residu. Residu dapat dikatakan random jika koefisien korelasi berada di dalam interval kepercayaan sebagaimana ditunjukkan pada Gambar 6(a).

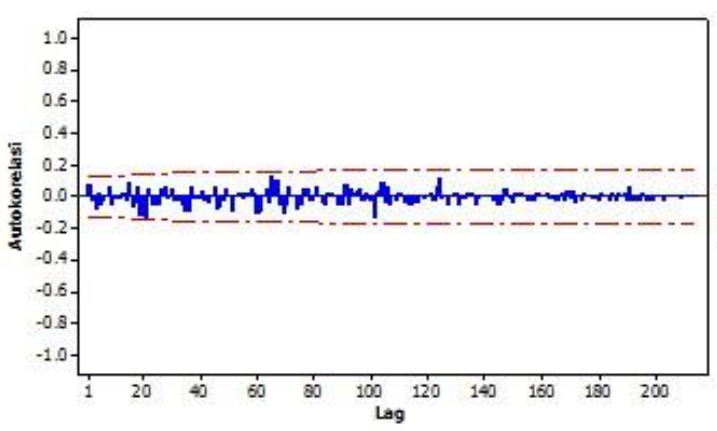

a) Plot Autokorelasi

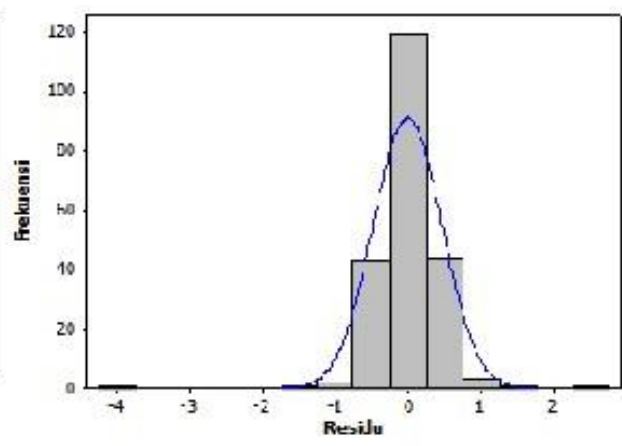

b) Plot Poligon Frekuensi

Gambar 6. Plot Residu DSARIMA $(0,1,[1,20,47])(0,1,1)^{48}(0,1,0)^{336}$

Pada uji kenormalan residu model $\operatorname{DSARIMA}(0,1,[1,20,47])(0,1,1)^{48}(0,1,0)^{336}$ menggunakan uji Kolmogorov Smirnov diperoleh $p$-value $=0,01$. Hal ini berarti bahwa residu tidak memenuhi asumsi kenormalan pada tingkat signifikansi $5 \%$. Berdasarkan Gambar 6(b), terlihat kurva menceng ke kiri dengan nilai skewness 
sebesar -1,9033 dan nilai kurtosis sebesar 22,4257, memperlihatkan keruncingan kurva leptokurtik. Residu model $\operatorname{DSARIMA}(0,1,[1,20,47])(0,1,1)^{48}(0,1,0)^{336}$ tidak berdistribusi normal, dimungkinkan karena adanya nilai-nilai ekstrim pada data. Menurut Gujarati ${ }^{[2]}$, asumsi kenormalan tidak terlalu penting pada model dengan ukuran sampel yang sangat besar. Mengacu pada Gujarati ${ }^{[2]}$, model $\operatorname{DSARIMA}(0,1,[1,20,47])(0,1,1)^{48}(0,1,0)^{336}$ dapat digunakan untuk meramalkan data penggunaan beban listrik. Hasil ramalan penggunaan beban listrik untuk periode 23 April 2013 pukul 00.00 sampai dengan 29 April 2013 pukul 23.30 menggunakan model DSARIMA $(0,1,[1,20,47])(0,1,1)^{48}(0,1,0)^{336}$ dan nilai yang sebenarnya diperlihatkan pada Gambar 7. Pada peramalan periode tersebut, model $\operatorname{DSARIMA}(0,1,[1,20,47])(0,1,1)^{48}(0,1,0)^{336}$ memberikan MAPE sebesar 6,09\%.

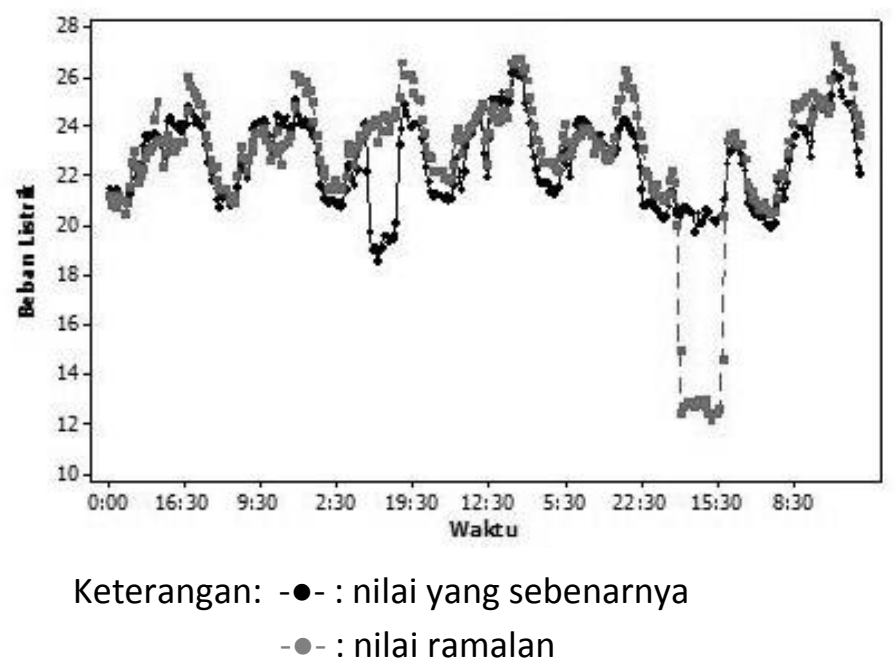

Gambar 7. Plot Runtun Waktu Hasil Ramalan dan Nilai yang Sebenarnya

\section{Kesimpulan}

Pada penelitian ini, dapat disimpulkan bahwa dari 102 hanya satu model yang memenuhi uji kerandoman residu yaitu $\operatorname{DSARIMA}(0,1,[1,20,47])(0,1,1)^{48}(0,1,0)^{336}$. Hasil peramalan untuk periode 23 April 2013 pukul 00.00 WIB hingga 29 April 2013 pukul 23.30 WIB menunjukkan nilai $M A P E$ sebesar 6,09\%. Hasil peramalan data penggunaan beban listrik GI Bawen memperlihatkan pola yang hampir sama terhadap data asli. Pada kasus ini, residu tidak berdistribusi normal karena diduga ada nilai-nilai ekstrim yang mempengaruhi estimasi parameter, sehingga perlu ada penelitian lebih lanjut untuk melakukan deteksi nilai-nilai ekstrim tersebut.

\section{DAFTAR PUSTAKA}

1. Box, G.E.P., Jenkins, G.M. and Reinsel, G.C, Time Series Analysis: Forecasting and Control,3 ed., Prentice Hall, Inc, New Jersey, 1994.

2. Gujarati, D.N., Basic Econometrics, 4 ed., Mc Graw Hill Companies, New York, 2006.

3. Hanke, J.E. and Dean, W.W., Business Forecasting, 8 ed., Prentice-Hall, New Jersey, 2006.

4. Ismail, Z. and Mahpol, K.A, Model for Forecasting Malaysian Electricity Generated, Matematika, 2005, 21, No. 2: 143 - 152. 
5. Ketenagalistrikan, Undang-undang Republik Indonesia No. 30 tahun 2009, Jakarta, 2009.

6. Mohamed, N., Maizah, H.A., and Suhartono, Forecasting Short Term Load Demand using Double Seasonal ARIMA Model, World Applied Sciences Journal 13 (2011), No. 1: 27 - 35.

7. Mohamed, N., Maizah, H.A., Zuhaimy, I. and Suhartono, Double Seasonal ARIMA Model for Forecasting Load Demand, Matematika 26 (2010), No. 2: 217 $-231$.

8. Mohamed, N., Maizah, H.A., Zuhaimy, I. and Suhartono, Improving Short Term Load Forecasting using Double Seasonal ARIMA Model, World Applied Sciences Journa, 2011, 15, No. 2: 231 - 233.

9. PT. PLN (Persero) P3B Jawa Bali, http://wwwpln.co.id/p3bjawabali, 2011.

10. Suhartono dan Endharta, A.J, Peramalan Konsumsi Listrik Jangka Pendek dengan Arima Musiman Ganda dan Elman-recurrent Neural Network, Jurnal Ilmiah Teknologi Informasi, 2009, Vol. 7, No. 4: 183 - 204

11. Taylor, J.W., Manezes, L.M. and McSharry, P.E., A Comparison of Univariate Methods for Forecasting Electricity Demand up to a day a head, International Journal of Forecasting, 2006, Vol. 22: 1 - 6.

12. Wei, W.W.S., Time Series Analysis: Univariate and Multivariate Method, Second Edition, Addison-Wesley Publishing Company, Inc., California, 2006. 